\title{
THE BINARY SYSTEM OF TRANSLATION IDEOLOGY: BETWEEN FOREIGNIZATION AND DOMESTICATION
}

\author{
AKHMAD BAIHAQI \\ University of Sultan Ageng Tirtayasa \\ E-mail:mr.qrider@yahoo.com
}

\begin{abstract}
This paper is intended to understand how translation ideology occurs on students' translation text of English Master Program at Postgraduate of University of Sultan Ageng Tirtayasa. The problem is formulated as follows; how does translation ideology occur on students' translation text of English Master Program at Postgraduate of University of Sultan Ageng Tirtayasa. Data of the research resulted from the students' translation text from English (SL) to Indonesian Language (TL). The result shows that the translation ideology of domestication is commonly occurred to avoid the awkwardness of the target text readers. This also makes the target texts have their readability and adjustability to TL culture and situation. On the contrary, the translation ideology of foreignization is mainly occurred to keep the relevance of the source text's linguistic and cultural values.
\end{abstract}

Keywords: translation ideology, foreignization, domestication 


\section{INTRODUCTION}

The study of the translation does not only involve giving the equivalent meaning in the target language, rather it involves considering the values of the target language (TL) and the source language (SL) whether they are belonging to linguistic or cultural. Linguistic here refers to lexical, grammatical, semantics, and stylistics; and cultural refers to context, topic, setting, and readership. Furthermore, equivalence is also highly influenced by the text function or skopos theory and audience design.

Essentially, the term of equivalence in translation is not merely referred to the form of expression but also relates to the meaning conveyed (Baihaqi, 2017). The term of translation equivalence here, as previously stated by Baker, classified in (1) Word Level and Above Word Level Equivalence, (2) Grammatical

Equivalence, (3) Textual Equivalence, and (4) Pragmatic Equivalence (Baker, 1992). The word level and above word level discuss the equivalence in term of morphemes, collocations, and idioms. Grammatical equivalence relates to the translation at dimensions of morphology and syntax. In particular, this translation equivalence relates to the functional aspects such as verb and noun; also the broader aspects such number, gender, person, voice, tense, and aspect. Textual equivalence is closely related to the cohesion relation (relation of the meaning) of the source language text into target language one. As an additional of the previous type, this translation equivalence includes analysis of reference, substitution, ellipsis, conjunction, and lexical cohesion. Pragmatic equivalence, the last, refers not only in terms of linguistic meaning but also to the situation meaning. Like the last type of translation equivalence, this gives the translator the smoothest and the most natural result of his/her target language version. This type deals with the analysis of coherence and implicature aspect. Thus, it considers that translation study is not only related to the linguistic area as the consequence of meaning but also to the stylistic and even the situation ones.

In terms of resulting equivalence of both meaning and style, it deals, at least, to cognitive, emotive, and rhetoric (Hoed, 2006). Cognitive denotes to the knowledge of both source and target language and the knowledge of the text which is being translated, emotive deals to the taste and nuances of meaning of both source and target language, and rhetoric mainly refers to the translator's language skill. In other cases, since translation study itself relates to any linguistics and even non-linguistics factors, it does not mean that those three 
components above will give a guarantee of the target language text's accuracy, readability, understandability to its target language readers. A lot of factors will take effect to the result of TL text whether from linguistic values, situational, and even cultural ones as previously stated above.

Some translators perhaps prefer to change the values of their source language texts; some others perhaps keeps the values of its source-language text. Both situations are occurred due to the tendency of their ideologies. The translation ideology, as previously proposed by Venuti in 1995 and Hatim and Mason in 1997, will affect the translator's tendency for changing the values of source language, or keeping the values of source language. For the reason, this paper tries to understand the translation ideology that occurred on students' translation text of English Master Program at Postgraduate of University of Sultan Ageng Tirtayasa. The writer, then, formulates the problem as follows: How does translation ideology occur on students' translation text of English Master Program at Postgraduate of University of Sultan Ageng Tirtayasa? The last, this research may contribute a brief explanation in the field of translation theory and practice, and it may also aid students, lecturers, researchers, and even translators in the field of translation studies.

In the beginning, a translator should know for whom his translation version is addressed to (audience design), and what is the primary purpose of his translation text (skopos theory). Those seem to be an obligation for a translator since it becomes the preliminary step in translating. Since the translator has considered the audience design and skopos theory, the next steps are deciding the methods and the procedures of translation (Hoed, 2006). Those steps are seen as the core of translation as the process of reproducing the meaning from source language (SL) text to target language (TL) one.

Every reproduction process in a translation study can not be separated, and it usually influenced by its ideology. It seems that ideology has a close relationship to the translation study since translation itself related to two different languages: source language and target language, and two different communities: source language readers and target language readers (Hoed, 2006). It is also claimed that all translations are ideological since the choice of a source text and the use to which the subsequent target text is put are determined by the interests, aims, and objectives of its translator (Hatim and Munday, 2004). Besides, any translation processes will also 
face two different

cultures: source language culture and target language culture.

The term of ideology perhaps commonly reflect the politics or even social life in every part of the world. In this case, it can be defined ideology as the tacit assumption, beliefs, and values system which are shared collectively by a social group (Hatim and Mason, 1997). In translation study, ideology commonly refers to the translator's value system, idea, and tendency to see the situation of both SL and TL texts' situation and readership (Baihaqi, 2017). Thus, it can be viewed that the term of ideology in translation study referred with translator basic assumption, beliefs, and values system to legitimate his/her interest, aim, and objectives to particular group (source language readers or target language ones). The ideology of translator will take into account as a reflection to his/her translation version on the target language text whether it puts emphasize on source language or target language one.

It has been argued that translation is not a neutral activity (Hatim and Mason, 1997). Therefore, every possibility, consciously or not, maybe occurred in the translation process. The choice of this possibility is implicitly presented as an ideological. In translation, the choice of this ideology is presented into domestication and foreignization translation (Hatim and Mason, 1997). The term of domestication and foreignization had attracted the attention of translation theorists for a long time. These ideologies had recommended as a problem solver in translation study especially if it faces the cultural problems.

The translation ideology of domestication has been recommended to make the translation reader-friendly, and this makes the translator 'invisible' on the one hand and implies 'an ethnocentric reduction of the foreign text to targetlanguage cultural values.' However, if the translation ideology of Foreignization is applied to a translation, the target language readers will feel that the translator is 'visible' and they will tell 'they are reading a translation.' This solution would recover the reputation of translators and highlight their importance (Venuti in Al-Dammad, 2008). Other states that the term of domestication referred if translators prefer changing the source language values and making them readable for the target language audience; on the other hand, foreignization referred if translators prefer keeping the values of the source language and exposing the audience to them (AlDammad, 2008). Similarly, the domestication ideology occurrs since the 
translator has a role as an author of the TL

text and gives priority to the purpose of producing TL text; however, foreignization occurred when the translator is an autonomous reader of SL text. The following are the examples for both domestication and foreignization translation version (adapted from AlDammad, 2008).

"Most of the Kuwaiti ruling family left to Saudi Arabia."

This translation is domesticated because the back translation reads:

\section{"Most of the Kuwaiti ruling family fled to Saudi Arabia."}

Using 'left' instead of 'fled' is intended by the translator to avoid embarrassment especially if he or she is working in Kuwait. This is due to the ideology of the translator. When translators use foreignization, they keep the SL values and make them salient in the TL. Translating verses of the Quran into English shows foreign elements to the English language readership as an example. Then, Al-Quran, An-Naba, verse: 7 , it is translated into English as:

"And the mountains as pegs"

The English meaning of this verse is:

"Mountains balance earth like anchors to a ship."

The foreignization here is aimed to break the sense of English into common daily language.

Further examples also can be observed as follow.

1. Domestication version:

ST : Lalu kini, siraman air kembang dahulu, midodareni. Sebelum esok menghadap penghulu. Tarub, janur, gamelan, dan gending kebogiro.

TT : And now, the sprinkle of water from an earthen jug. Before facing his servant tomorrow. The nuptial awning, woven palm leaves, the orchestra and wedding songs.

2. Foreignization version:

$\mathrm{TSu}:$ When Indonesia annexed the former Portuguese colony of east Timor in 1975 many Australians understood this as part of the process of decolonization. Other Australians were unhappy with this situation, believing that East Timor should become an independent country.

TSa : Ketika Indonesia mencaplok Timor Timur, bekas koloni Portugis di tahun 1975 banyak orang Australia yang melihatnya sebagai proses dekolonisasi. Banyak orang Australia yang beranggapan bahwa Timor Timur seharusnya menjadi negara yang merdeka.

(Adapted from Machali in Baihaqi, 2017.

In example 1, domestication can be seen in phrases siraman air kembang becomes the sprinkle of water from an earthen jug, and gamelan dan gending kebogiro becomes the orchestra and wedding songs. In example 2, then, foreignization can be observed in word annexed becomes mencaplok. This 
foreignization seems that in reality, Timor

Timur is not annexed, but they are integrated into Indonesia.

Domestication or foreignization translation also will be successful and precious since it was related to four logical themes analysis. The following are the discussion of those four logical themes.

1. Translator Cultural Background

The translators were successful as they were fluent since they had recognized for both source language and target language cultures. They could handle or minimize the translation problem when they had already mastered with cultural terms of both languages.

2. Authorship Full Recognition

Venuti claimed that the authorship full recognition would keep translators invisible because they limited their freedom. What comes to mind is without such recognition, translators will be more visible. Seemingly, they were interested in what they produced not in their reputation. Even their names are written in small font below the original writer's name, other times; there is only the writer's name.

3. Percentage of Translation Some translators did not consider that they tend to write in English, as it was

the lingua franca of the world. Venuti preferred a 'trade balance' that there was a balance between translation from one language and translation into another language. Unfortunately, the idea of comparing was not reasonable because every language had its characteristic. As a result, there would not be a 'trade balance.'

\section{The Cultural Complacency}

What Venuti condemned meant the application of one culture to another culture. A translator should deal not only with target language readers as part of target language culture but also with source language readers as part of the source language culture. Since the translator could coin both of these diverse cultures in his/her understandable and readable text, it meant he/she could coin cultural complacency (Venuti in Al-Dammad, 2008).

From the discussion, it can be viewed that both domestication and foreignization ideologies not only relate to the translators' preferences in changing or keeping the source language values, but they also give a more precious and successful result with the consideration of four logical themes above. Moreover, the domestication and 
foreignization ideologies will be drawn in both the

process and result of translation. Those ideologies can determine the process and the result of translation in term of linguistics system, and even in the situational one. In other words, both of translation ideologies will take effect in translation version within linguistic and cultural aspects, which those are relating with the translator selection and tendency.

In brief, domestication translation prefers to adapt source language values, linguistic and cultural, to the target language. Foreignization translation, in other words, prefers to preserve the linguistic and cultural values of the source language.

\section{METHOD}

This research is intended to know how translation ideology occurs on students' translation text of English Master Program at Postgraduate of University of Sultan Ageng Tirtayasa. Subjects of the research are students of English Master Program during the third semester.

In inferencing and analyzing the meaning and relation between word and context, it follows the fundamental rules for qualitative content analysis. These rules are the similarities between material and model, rule of analysis, categorial, and criteria of credibility and dependability (Mayring, 2009). Data of the research are based on students' translation texts while conducting translation practice in Advanced Translation subject.

\section{RESULT AND DISCUSSION}

Data of the research can be classified as follows.

Table 1. Domestication Translation Version

\begin{tabular}{c|l|l}
\hline No & \multicolumn{1}{|c}{ SL Version } & \multicolumn{1}{c}{ TL Version } \\
\hline 1 & $\begin{array}{l}\text { In the name of God, the Compassionate, the } \\
\text { Merciful. }\end{array}$ & $\begin{array}{l}\text { Dengan menyebut nama Allah yang maha } \\
\text { pengasih dan maha penyayang. }\end{array}$ \\
\hline 2 & Honor and pride to the priests. & Kehormatan dan kebahagiaan untuk para ulama. \\
\hline 3 & $\begin{array}{l}\text { The genuine ulema } \text { of Islam have never stopped } \\
\text { against the capitalists and landlords. }\end{array}$ & $\begin{array}{l}\text { Ulama Islam yang sejati tidak akan menyerah } \\
\text { melawan para kapitalis dan tuan tanah. }\end{array}$ \\
\hline 4 & $\begin{array}{l}\text { The genuine } \text { ulema } \text { of Islam have never stopped } \\
\text { against the capitalists and landlords. }\end{array}$ & $\begin{array}{l}\text { Ulama Islam yang sejati tidak akan menyerah } \\
\text { melawan para kapitalis dan tuan tanah. }\end{array}$ \\
\hline 5 & Through the war we can stand on our own feet. & Melalui perang kita bisa merdeka. \\
\hline
\end{tabular}


Table 2. Foreignization Translation Version

\begin{tabular}{c|l|l}
\hline No & \multicolumn{1}{|c}{ SL Version } & \multicolumn{1}{c}{ TL Version } \\
\hline 1 & $\begin{array}{l}\text { We have had the war against both of Western and } \\
\text { Eastern superpowers. }\end{array}$ & $\begin{array}{l}\text { Kita telah berperang melawan negara penguasa } \\
\text { dari belahan dunia barat dan timur. }\end{array}$ \\
\hline 2 & $\begin{array}{l}\text { We need ulema of Islam who was honest, } \\
\text { knowledgeable, and efficient in what he was } \\
\text { doing. }\end{array}$ & $\begin{array}{l}\text { Kita membutuhkan ulama Islam yang jujur, } \\
\text { berpengetahuan, dan efisien terhadap apa yang } \\
\text { dia lakukan. }\end{array}$ \\
\hline
\end{tabular}


The first version of domestication ideology can be discussed as follows: SL : In the name of „God," the Compassionate, the Merciful.

TL : Dengan menyebut nama „Allah" yang maha pengasih dan maha penyayang.

This version is domesticated because the back-translation is stated below:

BT : Dengan menyebut nama ,tuhan" yang maha pengasih dan maha penyayang.

Deciding,,Allah" rather than,, tuhan "here is intended to make the target language readers assumed that this version is referring to Al-Quran's verse „, bismillahirrohmanirrohim. "Besides, this domestication is also occurred because the translation text is aimed for Muslim readers.

The second version of domestication ideology can be discussed as below:

SL : Honor and pride to the ,priests."

TL : Kehormatan dan kebahagiaan untuk para ,ulama."

The back-translation of this version as follows:

BT : Kehormatan dan kebahagiaan untuk para ,pendeta."

Choosing ,ulama" than "pendeta" here is quite similar to the above domestication version. This version occurs because the translation text is aimed for Muslim readers. Besides, it is also intended to avoid such target language readers' awkwardness.
Next, the third version of domestication ideology can be analyzed as below:

SL: The „genuine" ulema of Islam have never stopped against the capitalists and landlords.

TL : Ulama Islam yang ,sejati" tidak akan menyerah melawan para kapitalis dan tuan tanah.

The back-translation of this version as follows:

BT : Ulama Islam yang ,asli“ tidak akan menyerah melawan para kapitalis dan tuan tanah.

Using , sejati instead of ,asli" is aimed to accentuate the target language readers that the term of ,ulema" here is not only related with the ,ulema" who has spiritually skillful but also they have their social awareness to its society. This domestication is also intended as an adjustment process from the translator to convince the target language readers as Muslim readers about the term of ,ulema" above.

The fourth domestication version can be discussed as follows:

SL : The genuine ulema of Islam have never "stopped" against the capitalists and landlords.

TL : Ulama Islam yang sejati tidak akan ,menyerah" melawan para kapitalis dan tuan tanah.

The back-translation of this version as follows:

BT : Ulama Islam yang sejati tidak akan ,berhenti" melawan para kapitalis dan tuan tanah. 
The reason for using ,menyerah" rather than ,berhenti" here is quite similar to the previous version. In this case, the option here is intended as an accentuation and adjustment to convince the target language readers as Muslim readers about the term of ,ulema" above.

The last domestication version can be explained as follows:

SL : Through the war we can ,stand on our own feet."

TL : Melalui perang kita bisa ,merdeka."

This version is also domesticated because of the back-translation as below:

BT : Melalui perang kita bisa ,, berdiri di atas kaki sendiri."

Using ,,merdeka instead of ,berdiri di atas kaki sendiri" here is intended to avoid target language readers' awkwardness and misinterpretation since this version relates to the translation of lexis, such phrases, collocations, and idioms.

Then, the first version of foreignization translation can be discussed as follows:

SL : We have had the war against both of Western and Eastern,, superpowers."

TL : Kita telah berperang melawan negara "penguasa" dari belahan dunia barat dan timur.

This version shows foreignization because the back-translation is stated below:

BT : Kita telah berperang melawan negara ,adikuasa" dari belahan dunia barat dan timur.

The reason for using ,penguasa " instead of „adikuasa" here is intended to give the sense of English daily usage. This version is also aimed to avoid such misconception and misinterpretation since it relates to the political view. In this case, the use of „penguasa" seems more appropriate and natural to source language text than the use of ,,adikuasa."

The second version of foreignization ideology can be explained as follow:

SL : We need ulema of Islam who was honest, knowledgeable, and „efficient" in what he was doing.

TL : Kita membutuhkan ulama Islam yang jujur, berpengetahuan, dan „efisien" terhadap apa yang dia lakukan.

This version shows foreignization because the back-translation as follows:

BT: Kita membutuhkan ulama Islam yang jujur, berpengetahuan, dan "mampu" terhadap apa yang dia lakukan.

The reason for using ,efisien " "rather than „матри " here is intended to share that the text is foreign. This gives a sense of English daily usage.

Based on the above discussions, it can be viewed that the domestication translation versions attempt to avoid the target language readers' awkwardness or embarrassment. This ideology also 
encourages the readable and adjustable target language text for its readers. The foreignization translation, on the other hand, it gives the sense of source language daily usage. It is also occurred to make the translation version proper to its source language text's linguistic value.

\section{CONCLUSION}

It can be discussed that the occurrence of domestication translation versions are intended to avoid the target language readers' awkwardness and embarrassment. It also results in the readable and adjustable target language linguistic values for its target language readers. On the other hand, foreignization seems to be occurred as an effort to convey the nuances of source language daily usage. Foreignization is also intended to reproduce the sense that translation version is foreign, and make it relevant to its source language linguistic values.

\section{REFERENCES}

Al-Dammad, Abdul Aziz. (2008). Domestication versus Foreignization in English and Arabic Translation. (http://www.proz.com)

Baihaqi, Akhmad. (2017). Penerjemahan dan Kesepadanan dalam Penerjemahan. Pandeglang, Staisman Press.

Baker, Mona. (1992). In Other Words: A Coursebook on Translation. London, Routledge.

Hatim, Basil., and Ian Mason. (1997) The Translator as Communicator. London, Routledge.

Hoed, Benny H. (2006). Penerjemahan dan Kebudayaan. Jakarta, Pustaka Jaya.

Machali, Rochayah. (2000). Pedoman bagi Penerjemah. Jakarta, PT Gramedia Widiasarana Indonesia.

Mayring, Philipp. (2009). Qualitative Content Analysis.

(http://www.qualitative-research.net). Venuti, Lawrence. (1995). The

Translator's Invisibility: A History of Translation. London, Routledg 
